\title{
Pulse oximetry curves in healthy children living at moderate altitude: a cross- sectional study from the Ecuadorian Andes
}

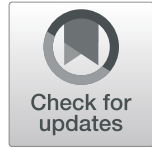

\author{
Vinicio Andrade ${ }^{1 *}$, Felipe Andrade ${ }^{1}$, Pablo Riofrio ${ }^{1}$, Fúlvio B. Nedel ${ }^{2,3}$, Miguel Martin $^{1,2,4}$ and \\ Natalia Romero-Sandoval ${ }^{1,2}$
}

\begin{abstract}
Background: In populations above 3,000 meters above sea level (m.a.s.l.) normal values of oxygen saturation (SpO2) above 90\% have been reported. Few studies have been conducted in cities of moderate altitude (between 2,500 and 3,000 $\mathrm{m}$ a.s.l). We set out to describe the range of SpO2 values measured with a pulse oximeter in healthy children between 1 month and 12 years of age living in an Ecuadorian Andean city.

Methods: A cross-sectional study was carried out in Quito, Ecuador, located at 2,810 m a.s.l. SpO2 measurement in healthy children of ages ranging from 1 month to 12 years of age residents in the city were recorded by pulse oximetry. Age and gender were recorded, and median and 2.5th and 5th percentile were drawn. Non parametric tests were used to compare differences in $\mathrm{SpO} 2$ values by age and gender.

Results: 1,378 healthy children were included for the study, 719 (52.2\%) males. The median SpO2 for the entire population was $94.5 \%$. No differences were observed between $\mathrm{SpO} 2$ median values by age and gender. The 2.5th percentile for global SpO2 measurements was 90\%, in children under 5 years of age was $91 \%$ and it was $90 \%$ in children older than 7 .

Conclusions: Our results provide SpO2 values for healthy children from 1 to 12 years old residents in Quito, a city of moderate altitude. The SpO2 percentile curve could contribute as a healthy range for the clinical evaluation of children residing at this altitude.
\end{abstract}

Keywords: pulse oximetry: reference value, children, altitude

\section{Background}

Oxygen saturation $(\mathrm{SpO} 2)$ is an indirect index of oxygen supply-to-demand balance $[1,2]$. Pulse oximetry provides information about patient's oxygenation status and is a reliable, simple, safe, accurate, and relative low cost method to monitor the patient as compared to expensive and labor-intensive methods [3, 4]. Patient's oxygenation status can show a reduced partial pressure of oxygen

\footnotetext{
* Correspondence: vinanmay@gmail.com

'School of Medicine, Universidad Internacional del Ecuador, Av. Simón Bolívar and Av. Jorge Fernández. Quito, Quito, Ecuador

Full list of author information is available at the end of the article
}

and/or decreased oxygen saturation in arterial blood and in this case, it should be called hypoxemia [4]. Hypoxemia in children has been associated with increased mortality and is a frequent complication in cases of pneumonia, bronchiolitis, asthma and other severe diseases such as sepsis [5]. The recognition of hypoxemia among children with pneumonia contributes to diagnosis, is crucial in patient management, and helps in determining prognosis [5-7].

The World Health Organization (WHO) recommends an oxygen saturation threshold value of $90 \%$ measured by pulse oximetry, as the cut-off point for oxygen

(c) The Author(s). 2020 Open Access This article is licensed under a Creative Commons Attribution 4.0 International License, which permits use, sharing, adaptation, distribution and reproduction in any medium or format, as long as you give appropriate credit to the original author(s) and the source, provide a link to the Creative Commons licence, and indicate if changes were made. The images or other third party material in this article are included in the article's Creative Commons licence, unless indicated otherwise in a credit line to the material. If material is not included in the article's Creative Commons licence and your intended use is not permitted by statutory regulation or exceeds the permitted use, you will need to obtain permission directly from the copyright holder. To view a copy of this licence, visit http://creativecommons.org/licenses/by/4.0/. The Creative Commons Public Domain Dedication waiver (http://creativecommons.org/publicdomain/zero/1.0/) applies to the data made available in this article, unless otherwise stated in a credit line to the data. 
administration in populations living at 2,500 $\mathrm{m}$ a.s.l. or less [6]. In clinical practice, the "normal" $\mathrm{SpO} 2$ at sea level has been estimated to be between $95 \%$ and $100 \%$, however, several authors consider that values of $95 \%$ and 96\% were abnormal [3]. In altitudes above 3,000 m a.s.l, where oxygen saturation values are lower than at sea level, the 90\% cut-off point could be less useful [8].

There are few studies about $\mathrm{SpO} 2$ values performed in cities between 2,000 and 3,000 $\mathrm{m}$ a.s.l [9-11]. In order to contribute to the best comprehension about $\mathrm{SpO} 2$ values in healthy children living at moderate altitude, our study was devised to describe the values range of $\mathrm{SpO} 2$ measured with a pulse oximeter in healthy children between 1 month and 12 years of age living at 2,810 $\mathrm{m}$ a.s.l.

\section{Methods}

\section{Subjects and methods}

This cross-sectional study was conducted between $\mathrm{Au}-$ gust 2017 and June 2018. We invited 1,516 children residents in Quito, aged between 1 month and 12 years old, who sought preventive medical attention at three primary health-care centers (Lucha de los Pobres Healthcare Center, Cotocollao Health-care Center and Clínica Pichincha), three elementary schools (Escuela Francisco Salazar, Centro del Muchacho Trabajador Cotocollao and Centro del Muchacho Trabajador La Marín) and nine kindergarten municipal schools (Abdón Calderón, Andalucía, Carapungo, Colibrí, Cotocollao, Empleados Municipales, Ipiales, La Carolina and Santa Clara) to participate. Non-probabilistic and convenience sampling were used because age and gender distribution at the schools and health-care centers was unknown. The centers are located at an altitude between 2,740 and 2, $901 \mathrm{~m}$ a.s.l (average $2,810 \mathrm{~m}$ a.s.l). Ambient temperature throughout the study was, on average, $14.4{ }^{\circ} \mathrm{C}$ (11.5$20.8{ }^{\circ} \mathrm{C}$ ) and humidity average was $72.2 \%(52-81 \%)$ as reported by Ecuador's National Institute of Meteorology and Hydrology[12].

We included children who resided in the city at least 2 months before the study, similar criteria used in other study [13], and children younger than 2 months must have been born and remain living in the city until they were examined. Exclusion criteria included a registered axillary temperature $>37.5 \mathrm{C}^{\circ}$ at the time of evaluation, history of respiratory symptoms in the two weeks prior to evaluation, any abnormal cardio-respiratory signs during physical examination, history of chronic cardiorespiratory disease, history of neonatal respiratory disease, history of blood component transfusion in the six months prior to evaluation, and the presence of malnutrition, defined as a Z-score less than - 2SD for either height for age or weight for height $[9,10]$.

Children were enrolled in the study after written informed consent obtained from their parents. The study was approved by the Universidad Internacional del Ecuador Ethics Committee, registered code CEU-005-16 and by the health committee at each center participating in the study. Information on the study was provided to the directive councils and medical teams at each institution.

Fifteen students from fourth year of a school of medicine were rigorously trained in anthropometric measurements and pulse oximetry assessment by the standardization method of the Central America and Panama Institute of Nutrition (INCAP) [14]. To manage measurement bias, the students' measurements were compared against a pediatrician's reference pattern, establishing a maximum margin of error of $0.2 \mathrm{~kg}$ for weight and $0.5 \mathrm{~cm}$ for length and height [14].

\section{Variable definition}

Weight and height were measured using high fidelity equipment (Health-o-Meter 498KL and 593KL, USA), regulated and previously calibrated by the Ecuadorian Institute of Normalization. Respiratory frequency was obtained through observation in calm and alert children, visually counting thoracic and abdominal movements over one minute. Temperature was assessed with a flexible digital thermometer (Omron MC-343F, Mexico), placed in children's armpit until a reading signal was obtained. Heart rate and $\mathrm{SpO} 2$ were evaluated using automatically calibrated non-invasive pulse oximeters (Huntleigh MP1R Smartsigns ${ }^{\ominus}$ MiniPulse Huntleigh Healthcare Ltd, Cardiff, United Kingdom). The pulse oximeter used measured functional oxygen saturation with a precision range of $\pm 2 \%$. Pulse oximetry was assessed in calm and alert children. Wrap-around style and foldover-style probes were used, depending on the subject's age, and placed either on right hand's index finger or the big toe for infants. Nail polish remover was provided for subjects who had nail polish present at the time of the test. The $\mathrm{SpO} 2$ measurements were considered adequate when a plethysmographic waveforms of perfusion levelled-off on its high end and remained on the output screen for at least 2 minutes. Then, $\mathrm{SpO} 2$ measurements and pulse rate, were recorded every 10 seconds for a total of three measurements, and the average was used to determine $\mathrm{SpO} 2$ for each study subject [6, 15-17].

\section{Statistical Analysis}

Descriptive statistical tests were run for clinical measurements, and 2.5th percentile, 5th percentile, 25th percentile (Q1) and 75th percentile (Q3) for SpO2 distribution. The Kruskal-Wallis test was used to compare differences in $\mathrm{SpO} 2$ medians by age groups, MannWhitney $\mathrm{U}$ test was used to compare medians between males and females. Statistical significance was accepted with $p<0.05$. Smooth lines were designed for percentiles 
2.5th and 5th for $\mathrm{SpO} 2$ using the Spline method (smooth.spline function in $\mathrm{R}$, with a 7 degree freedom range). All data was registered in the digital survey platform Survey Monkey, and analyses were performed using SPSS $^{\circ}$, version 24. Graphics were designed using R version 4.3.

\section{Results}

1,516 children were invited to participate. A total of 1 , 378 (90.9\%) subjects were included for the study, of which $719(52.2 \%)$ were male. 138 children were excluded of which 7 were for not being residents of Quito, 56 had fever, 141 presented any cardiorespiratory symptoms, 31 presented stunting and 15 acute malnutrition. 13 had history of chronic cardiorespiratory disease, 3 had history of neonatal respiratory disease, and 1 had blood transfusion prior. 55 (39.8\%) had only one exclusion criteria and $8(5.8 \%)$ had 4 . Measurements characteristics of the included group are listed in Table 1.

The overall SpO2 lowest and highest values were 87\% and 99\%. Median, 2.5th, 5th, 25th (Q1) and 75th percentile (Q3) for $\mathrm{SpO} 2$ by age are listed in Table 2.

$\mathrm{SpO} 2$ at 12 years of age was the lowest median value (94\%), and the highest median value was observed in children aged 1 year (95\%); no significant differences in $\mathrm{SpO} 2$ median values were found between age (KruskalWallis Chi square test $=7.94, \mathrm{df}=11, p=0.72$ ).

Figure 1 shows the smooth percentile lines for $\mathrm{SpO} 2$ corresponding to percentiles 5th and 2.5th in all participants by age. It is noteworthy that in children between the ages of 7 and 9 the $\mathrm{SpO} 2$ value for percentile 2.5th was between $89 \%$ and $90 \%$, while in other age groups the values recorded were between 90 and $91 \%$.

Figure 2 represents $\mathrm{SpO} 2$ percentile lines for male population, value percentile 2.5th for $\mathrm{SpO} 2$ was between $89 \%$ and $90 \%$ for children younger than 1 year and of 8 and 9 years of age, respectively. Figure 3 represents the same data for females. Values 2.5th percentile for $\mathrm{SpO} 2$ were between $89 \%$ and $90 \%$ from 4 to 11 years of age. No differences were observed by gender (Mann-Whitney $\mathrm{U}$ test, $\mathrm{z}=-1,095 p=0.273$ ).

\section{Discussion}

The use of pulse oximetry is advised in order to increase detection of hypoxemia, considering normal $\mathrm{SpO} 2$ range values at higher altitudes $[5,8]$. Some studies that reported $\mathrm{SpO} 2$ measurements by average have showed $\mathrm{SpO} 2$ value is close to $99 \%$ at sea level and appears to decrease to $97 \%$ after 1500 to $1600 \mathrm{~m}$ a.s.l $[15,17,18]$. Furthermore, at $3000 \mathrm{~m}$ a.s.l, mean $\mathrm{SpO} 2$ values of $89.6 \%$ [19] or even $85.7 \%$ have been reported [20]. Lozano et al. at Bogotá-Colombia (2600 m a.s.l) have reported mean $\mathrm{SpO} 2$ value of 93.3\% (SD 2.05\%) [10] and Nicholas et al. at Colorado-USA (2800 m a.s.l) of $91.7 \%$ (SD 2.1\%) [9]. Because SpO2 levels are not normally distributed, it seems appropriate to report the data in median values and percentile values [8]. We present a curve with the medians and 5th and 2.5th percentiles of $\mathrm{SpO} 2$ of children from 1 month to 12 years permanent residents in the city of Quito, at $2810 \mathrm{~m}$ a.s.l. We did not find significant differences by children age or sex.

The median for global $\mathrm{SpO} 2$ measurements was $94.67 \%$, 5th percentile was $91.67 \%$, and 2.5 th percentile was $90.67 \%$. Rojas-Camayo et al. in children aged 1 to 5

Table 1 Clinical measurements characteristics by age group (mean and standard deviation)

\begin{tabular}{|c|c|c|c|c|c|c|}
\hline Age (years) & $\mathrm{n}$ (percentage of total) & $\begin{array}{l}\text { HR beats/min } \\
\text { mean (SD) }\end{array}$ & $\begin{array}{l}\text { RR breaths/min } \\
\text { mean (SD) }\end{array}$ & $\begin{array}{l}\mathrm{BMI} \mathrm{Kg} / \mathrm{m}^{2} \\
\text { mean (SD) }\end{array}$ & $\begin{array}{l}\text { Height m } \\
\text { mean (SD) }\end{array}$ & $\begin{array}{l}\text { Temp }{ }^{\circ} \mathrm{C} \\
\text { mean (SD) }\end{array}$ \\
\hline$<1$ & $167(12.1)$ & $132.8(14.3)$ & $43.6(9.2)$ & $16.6(1.8)$ & $0.64(0.1)$ & $36.8(0.2)$ \\
\hline 1 & $58(4.2)$ & $125.4(12.0)$ & $33.8(5.4)$ & $16.4(1.4)$ & $0.78(0.1)$ & $36.7(0.4)$ \\
\hline 2 & $149(10.8)$ & $113.4(10.9)$ & $30.1(4.4)$ & $16.27(1.4)$ & $0.87(0.0)$ & $36.6(0.4)$ \\
\hline 3 & $154(11.2)$ & 105.9(11.2) & $27.1(3.6)$ & $16.0(1.3)$ & $0.95(0.1)$ & $36.6(0.4)$ \\
\hline 4 & $155(11.2)$ & $100.6(11.2)$ & $26.0(3.3)$ & $16.0(1.4)$ & $1.00(0.0)$ & $36.6(0.4)$ \\
\hline 5 & $111(8.1)$ & 98.4(11.9) & $25.9(3.1)$ & $16.0(1.3)$ & $1.06(0.1)$ & $36.6(0.4)$ \\
\hline 6 & $74(5.4)$ & $88.8(12.6)$ & $24.5(3.8)$ & $16.1(2.4)$ & $1.13(0.1)$ & $36.7(0.4)$ \\
\hline 7 & $101(7.3)$ & $91.7(12.4)$ & $26.1(3.5)$ & 16.3(1.9) & $1.19(0.6)$ & $36.6(0.4)$ \\
\hline 8 & 93. (6.7) & $88.0(11.1)$ & $25.9(3.9)$ & $17.0(2.3)$ & $1.24(0.1)$ & $36.7(0.4)$ \\
\hline 9 & $96(7.0)$ & $87.9(12.6)$ & $25.2(4.3)$ & $17.0(1.9)$ & $1.28(0.6)$ & $36.6(0.4)$ \\
\hline 10 & $85(6.2)$ & $84.0(11.4)$ & $24.8(3.9)$ & $17.5(2.1)$ & $1.33(0.1)$ & $36.5(0.4)$ \\
\hline 11 & $100(7.3)$ & $82.2(11.1)$ & $24.1(3.9)$ & $18.1(2.4)$ & $1.38(0.1)$ & $36.6(0.4)$ \\
\hline 12 & $35(2.5)$ & $83.0(11.3)$ & $24.0(2.7)$ & $18.1(1.9)$ & $1.41(0.1)$ & $36.5(0.4)$ \\
\hline
\end{tabular}

Heart Rate (HR) defined as beats per minute. Respiratory Rate (RR) defined as breaths per minute. Body Mass Index (BMI). Height measured in meters (m) and Body temperature measured in Celsius degrees $\left({ }^{\circ} \mathrm{C}\right)$. 
Table 2 Distribution of oxygen saturation measured by pulse oximetry by age

\begin{tabular}{lccccc}
\hline Age (years) & Median & 2.5th Percentile & 5th Percentile & 25th Percentile (Q1) & 75th Percentile (Q3) \\
\hline$<1$ & 95.1 & 90.0 & 91.3 & 93.7 & 96.7 \\
1 & 95.3 & 91.9 & 92.7 & 94.3 & 96.0 \\
2 & 95.0 & 90.7 & 91.8 & 93.7 & 96.0 \\
3 & 95.0 & 91.8 & 92.3 & 94.0 & 96.0 \\
4 & 95.0 & 90.6 & 91.6 & 94.0 & 95.7 \\
5 & 94.3 & 91.3 & 91.7 & 93.3 & 95.3 \\
6 & 94.3 & 90.4 & 91.2 & 93.3 & 95.7 \\
7 & 94.3 & 90.2 & 91.6 & 95.3 & 95.7 \\
8 & 94.3 & 90.2 & 91.6 & 93.3 & 95.3 \\
9 & 94.3 & 89.2 & 91.6 & 93.0 & 95.3 \\
10 & 94.3 & 90.7 & 91.3 & 93.3 & 95.3 \\
11 & 94.0 & 91.0 & 96.7 & 93.0 & 95.0 \\
12 & 93.8 & 90.7 & 91.8 & 92.8 & 94.7 \\
Global & 94.7 & 90.7 & 91.7 & 93.4 & \\
\hline
\end{tabular}

years, report at $2880 \mathrm{~m}$ a.s.l, $\mathrm{SpO} 2$ median value of $95 \%$, 2.5th percentile was $91 \%$ [21]. In a recent study, Tüshaus et al. obtained an altitude-adaptive $\mathrm{SpO} 2$ computer model and proposed a model derived altitude-adaptive abnormal $\mathrm{SpO} 2$ threshold for an abnormal range that could indicate hypoxemia, in healthy children living permanently at altitudes up to $4000 \mathrm{~m}$ a.s.l [11]. They used the physiological model of the oxygen cascade and incorporated the technical tolerances that accounted for the accuracy of pulse oximeters (+ $-2 \%)$. With this model, the median at $2800 \mathrm{~m}$ a.s.l was $93 \%$ with lower healthy range of $88 \%$, and abnormal $\mathrm{SpO} 2$ threshold of $86 \%$. To evaluate the model, the authors compared it with an empirical dataset of 297 children residing between 2000 and $3900 \mathrm{~m}$ a.s.l. In that empirical study, they report that at an altitude of $2800 \mathrm{~m}$ a.s.l median $\mathrm{SpO} 2$ was $95.2 \%$ and 2.5 th percentile was $90 \%[11]$. Our median and 2.5th percentile values presented similar

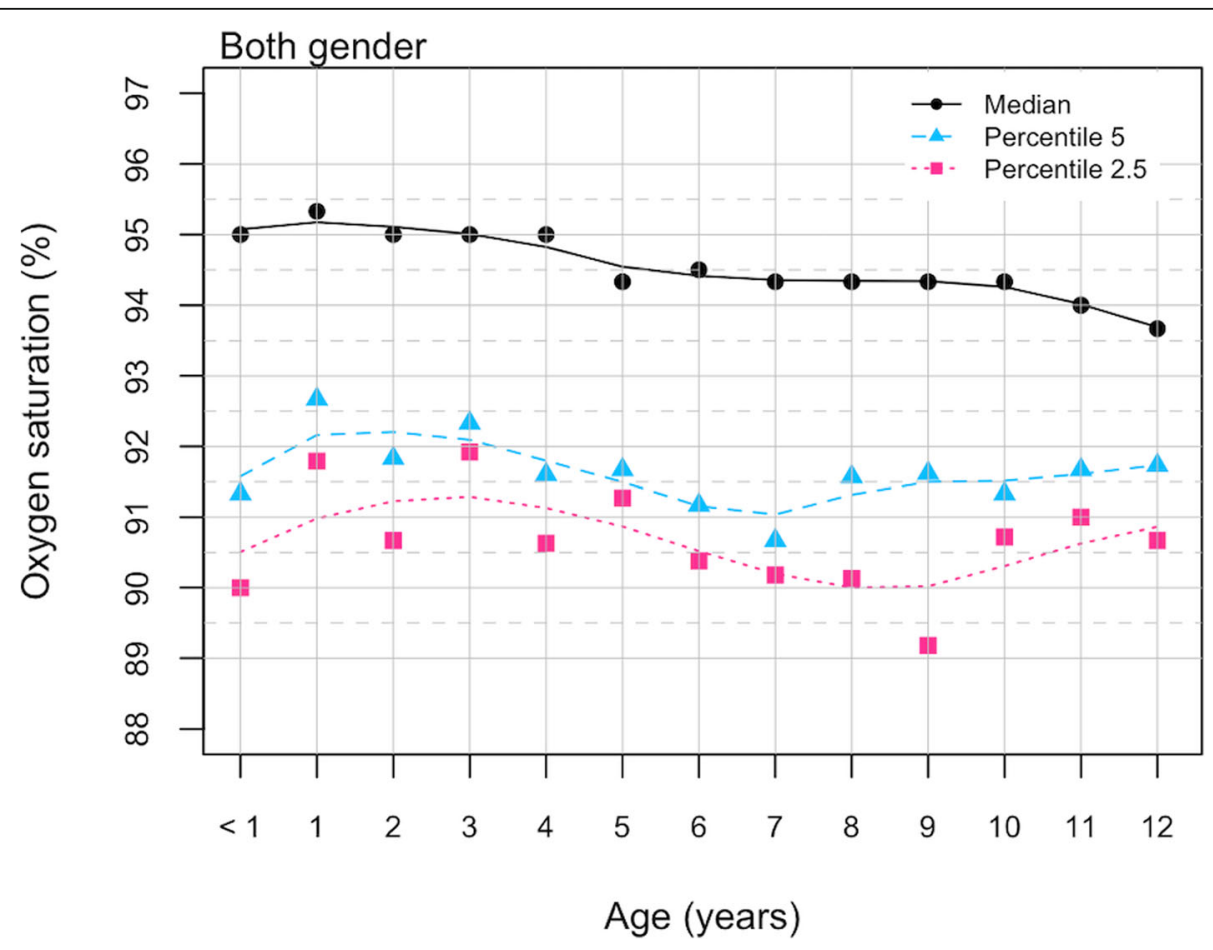

Fig. 1 SpO2 percentile values by age. Children residents in Quito, august 2017-june 2018 


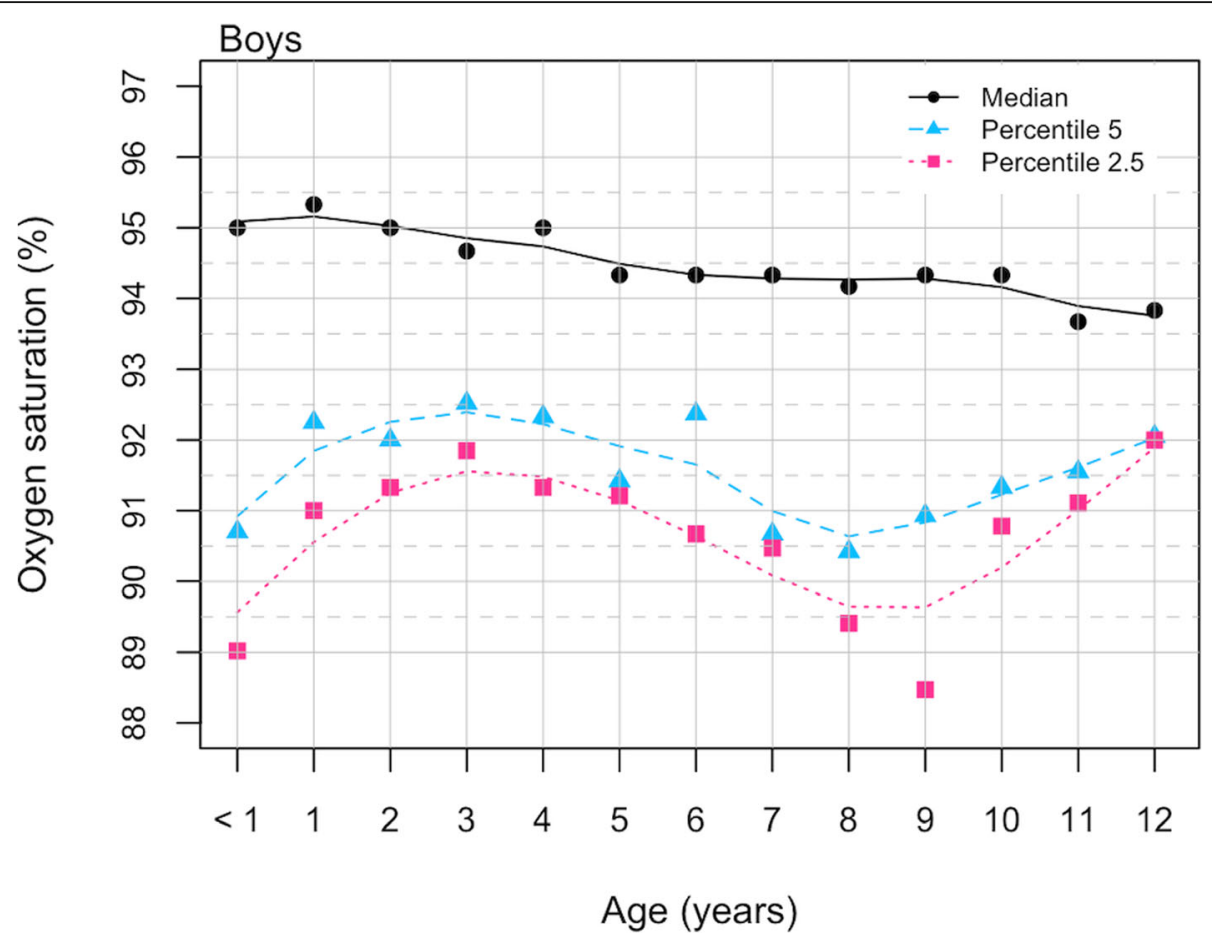

Fig. 2 SpO2 percentile values for age in boys residents in Quito, august 2017-june 2018

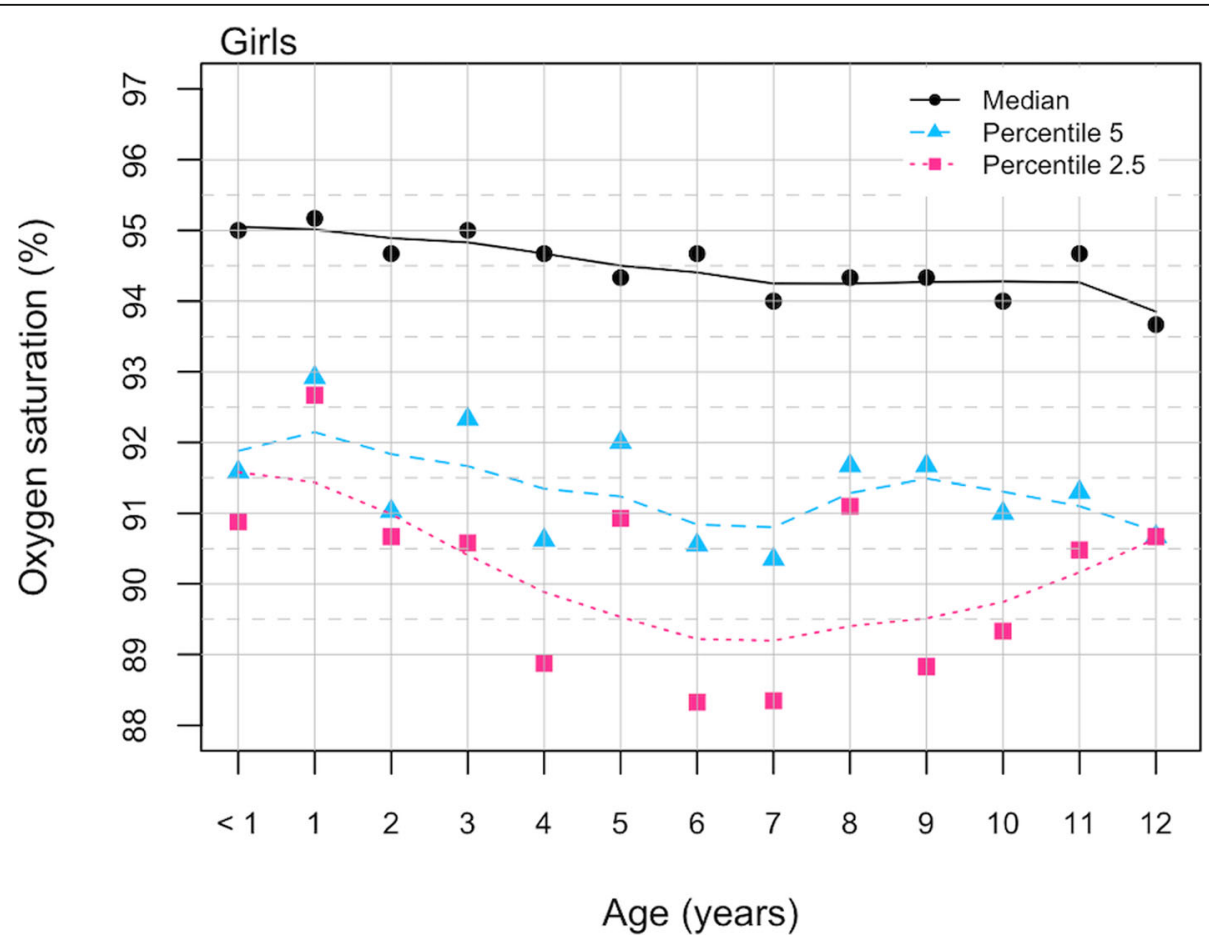

Fig. 3 SpO2 percentile values for age in girls residents in Quito, august 2017-june 2018 
results to those of Rojas-Camayo and the empirical study of Tüshaus et al. According to the physiological model of Tüshaus et al., the median value is similar, but the 2.5th percentile is lower. It is possible that this difference is due to the fact that the altitude-adaptive model is physiological and takes into account the pulse oximeters accuracy.

Pulse oximetry is a non-invasive and relative low-cost assessment method able to reduce child mortality by accurately diagnosing hypoxemia, increasing the possibilities of early and effective treatment [21]. Unreal $\mathrm{SpO} 2$ values could increase hospital admissions and hospital stays with subsequent iatrogenic risks and misuse of resources [21, 22]. Without pulse oximetry, the management of pediatric patients depends on precise identification of the clinical signs of hypoxemia, which are not always easy to assess in all patients. Clinical signs alone are unreliable for the detection of hypoxaemia [23].

Pulse oximetry identifies between 20 and 30\% more cases than clinical signs alone [21, 22, 24, 25]. However, the determination of a threshold to identify hypoxemia is difficult, especially in high altitude populations [26]. Some studies have previously used average $\mathrm{SpO} 2$ values $-2 \mathrm{SD}$ to define hypoxemia, however others have used the 2.5th percentile measurement as a cut-off point to decide to use oxygen [8]. Subhi et al., developed a statistical model of $\mathrm{SpO} 2$ distribution from sea level to $4000 \mathrm{~m}$ a.s.l. using meta regression based on 14 observational studies of healthy children. At an altitude of $2500 \mathrm{~m}$ a.s.l the 2.5 th percentile was $90 \%$ and at $2800 \mathrm{~m}$ a.s.l was $88 \%$. It suggests that for altitudes greater than $2500 \mathrm{~m}$ a.s.l the $\mathrm{SpO} 2$ threshold for identifying children requiring oxygen is $85 \%$ although it is not clearly defined how the threshold was chosen [8]. The threshold obtained with the Tüshaus altitude-adaptive model at 2800 m.a.s.l was $86 \%$ [11]. It is possible, that our results are related to "normality" in "children at community settings without respiratory symptoms and not fever living at moderate altitude", however, the 2.5 th percentile values could be conservative to be considered as a threshold to define hypoxemia or the need to administer supplemental oxygen. It is very important to consider the accuracy range of the pulse oximeter used $(+-2 \%)$ [11].

Physicians should consider the patient's clinical condition to make the decision to use oxygen therapy, especially in places where we have limited availability of resources. It would be important to evaluate $\mathrm{SpO} 2$ in children with low respiratory disease at moderate altitude to propose cut-off points for supplemental oxygen administration.

There are some limitations to the study. (1) Measurements were carried out in children between 1 month and 12 years of age living in Quito, so the results obtained cannot apply to patients who have not adapted to altitude. (2) All children in the sample had their medical records and physical examination taken but did not undergo laboratory testing for parameters such as serum hemoglobin, arterial blood gas testing or chest X-rays to discard other pathologies not found on clinical evaluation. (3) Although we carry out a standardization of personnel in the use of the pulse oximeter, we cannot totally exclude possibilities of error in the measurement of $\mathrm{SpO} 2$ such as incorrect positioning of the probe or insufficient perfusion. (4) In this study we did not set out to compare the $\mathrm{SpO} 2$ results between the group that met the inclusion criteria with the excluded group; However, this comparison could provide additional information.

\section{Conclusions}

Our results provide $\mathrm{SpO} 2$ values for healthy resident children from 1 to 12 years old at 2810 m. a.s.l., which could be considered as healthy ranges. $\mathrm{SpO} 2$ percentile curve could contribute as a reference range for the clinical evaluation of resident's children at this altitude.

\section{Abbreviations}

SpO2: Oxygen Saturation; WHO: World Health Organization; $m$ a.s.l: Meters above sea level; UIDE: Universidad Internacional del Ecuador

\section{Acknowledgements}

The authors express their gratitude to children, their parents and teachers for their participation in the study. We thank also students of School of Medicine for their support in the fieldwork.

\section{Authors' contributions}

VA and NR conceptualized and designed the study, drafted the initial manuscript, and reviewed and revised the manuscript. PB and FA designed the data collection instruments and collected data. MM and FN carried out the initial analyses and reviewed and revised the manuscript. All authors approved the final manuscript as submitted and agree to be accountable for all aspects of the work.

\section{Funding}

All phases, design of the study and collection, analysis, and interpretation of data and in writing the manuscript were supported by Universidad Internacional del Ecuador, grant number EDM-INV-11-17. Dr. Nedel, who participated in analysis, interpretation of data and in writing the manuscript was supported by Universidad Federal de Santa Catarina. Dr. Martin who participated in design, analysis, interpretation of data and in writing the manuscript was supported by Universidad Autonoma de Barcelona.

\section{Availability of data and materials}

Non-identified individual participant data (including data dictionaries) will be made available, in addition to study protocols, the statistical analysis plan, and the informed consent form. The data that support the findings of this study are available in DSpace in the following identifier https://repositorio. uide.edu.ec/handle/37000/4228. The data will be made available upon publication to researchers who provide a methodologically sound proposal for use in achieving the goals of the approved proposal. Proposals should be submitted to vinanmay@gmail.com.

\section{Ethics approval and consent to participate}

Subjects were enrolled in the study after written informed consent obtained from their parents. The study was approved by the Universidad Internacional del Ecuador Ethics Committee registered code CEU-005-16, and by the health committee at each center participating in the study. The study was conducted according ethical principles for medical research involving human 
subjects (Declaration of Helsinki). Information on the study was provided to the directive councils and medical teams at each institution.

\section{Consent for publication}

Subjects were enrolled in the study after written informed consent obtained from their parents. No other personal identifiable information will be shared outside of the study.

\section{Competing interests}

The other authors have indicated they have no potential conflicts of interest to disclose.

\section{Author details}

${ }^{1}$ School of Medicine, Universidad Internacional del Ecuador, Av. Simón Bolívar and Av. Jorge Fernández. Quito, Quito, Ecuador. ${ }^{2}$ Grups de Recerca d'Amèrica i ÀfricaLlatines- GRAAL, Barcelona, Spain. ${ }^{3}$ Departamento de Saudé Pública, Universidade Federal de Santa Catarina, Florianópolis, Brasil. ${ }^{4}$ Facultad de Medicina, Universidad Autónoma de Barcelona, Barcelona, Spain.

Received: 28 April 2020 Accepted: 8 September 2020

Published online: 18 September 2020

\section{References}

1. Hartog C, Bloos F. Venous oxygen saturation. Best Pract Res Clin Anaesthesiol. 2014;28:419-28. doi:https://doi.org/10.1016/j.bpa.2014.09.006.

2. Walton RAL, Hansen BD. Venous oxygen saturation in critical illness. J Vet Emerg Crit Care. 2018;28:387-97. doi:https://doi.org/10.1111/vec.12749.

3. Elder JW, Baraff SB, Gaschler WN, Baraff LJ. Pulse Oxygen Saturation Values in a Healthy School-Aged Population. Pediatr Emerg Care. 2015;31:645-7. doi:https://doi.org/10.1097/PEC.0000000000000331.

4. Van Meter A, Williams U, Zavala A, Kee J, Rebello E, Tsai J, et al. Beat to Beat: A Measured Look at the History of Pulse Oximetry. J Anesth Hist. 2017;3:246. doi:https://doi.org/10.1016/j.janh.2016.12.003.

5. Subhi R, Adamson M, Campbell H, Weber M, Smith K, Duke T. The prevalence of hypoxaemia among ill children in developing countries: a systematic review. Lancet Infect Dis. 2009;9:219-27. doi:https://doi.org/10. 1016/S1473-3099(09)70071-4

6. World Health Organization. Oxygen therapy for children: a manual for health workers. Geneva: WHO Document Production Services; 2016. http:// apps.who.int/iris/bitstream/10665/204584/1/9789241549554_eng.pdf.

7. Fouzas S, Priftis KN, Anthracopoulos MB. Pulse oximetry in pediatric practice. Pediatrics. 2011;128:740-52. doi:https://doi.org/10.1542/peds.2011-0271.

8. Subhi R, Smith K, Duke T. When should oxygen be given to children at high altitude? A systematic review to define altitude-specific hypoxaemia. Arch Dis Child. 2009;94:6-10. doi:https://doi.org/10.1136/adc.2008.138362.

9. Nicholas $\mathrm{R}$, Yaron $\mathrm{M}$, Reeves J. Oxygen saturation in children living at moderate altitude. J Am Board Fam Pract. 1993;6:452-6. http://www.ncbi. nlm.nih.gov/pubmed/8213235.

10. Lozano J, Duque O, Buitrago T, Behaine S. Pulse oximetry reference values at high altitude. Arch Dis Child. 1992;67:299-301.

11. Tüshaus L, Moreo M, Zhang J, Hartinger SM, Mäusezahl D, Karlen W. Physiologically driven, altitude-adaptive model for the interpretation of pediatric oxygen saturation at altitudes above 2,000 m a.s.l. J Appl Physiol. 2019;127:847-57. doi:https://doi.org/10.1152/japplphysiol.00478.2018.

12. Instituto Nacional De Meteorologia e Hidrologia. Series de datos Meteorologicos. Quito: Instituto Nacional De Meteorologia e Hidrologia; 2016.

13. Zubieta-Calleja GR, Paulev P-E, Zubieta-Calleja L, Zubieta-Castillo G. Altitude adaptation through hematocrit changes. J Physiol Pharmacol. 2007;58 Suppl 5 Pt 2:811-8. http://www.ncbi.nlm.nih.gov/pubmed/18204195.

14. Intituto de Nutricion de Centro America y Panama. Guía ténica para estandarización en procedimientos, análisis e interpretación de indicadores antropométricos según OMS. SICA, INCAP; 2012. https://www.sdgfund.org/ es/guía-técnica-para-la-estandarización-en-procesamiento-análisis-einterpretación-de-indicadores.

15. Duke T, Blaschke A, Bonkowsky J. Hypoxaemia in acute respiratory and nonrespiratory illnesses in neonates and children in a developing country. Arch Dis Child. 2002;86:108-12. http://ovidsp.ovid.com/ovidweb.cgi?T=JS. \&PAGE=reference $\& D=$ =med5\&NEWS $=\mathrm{N} \& A N=2002054717$.
16. Salyer JW. Neonatal and pediatric pulse oximetry. Respir Care. 2003:48:38698. http://www.ncbi.n/m.nih.gov/pubmed/12667266.

17. Balasubramanian S, Suresh N, Ravichandran C, Dinesh Chand GH. Reference values for oxygen saturation by pulse oximetry in healthy children at sea level in Chennai. Ann Trop Paediatr. 2006;26:95-9.

18. Thilo EH, Park-Moore B, Berman ER, Carson BS. Oxygen Saturation by Pulse Oximetry in Healthy Infants at an Altitude of $1610 \mathrm{M}(5280 \mathrm{ft})$. What is Normal? Am J Dis Child. 1991;145:1137. doi:https://doi.org/10.1097/ 00132586-199208000-00055.

19. Huicho L, Pawson I, Leon-Velarde F, Rivera-Ch M, Pacheco A, Muro M, et al. Oxygen saturation and heart rate in healthy school children and adolescents living at high altitude. Am J Hum Biol. 2001;13:761-70. http:// ovidsp.ovid.com/ovidweb.cgi?T=JS. \&PAGE=reference\&D=emed5\&NEWS= $N \& A N=2001412816$

20. Schult S, Canelo-Aybar C. Oxygen Saturation in Healthy Children Aged 5 to 16 Years Residing in Huayllay, Peru at 4340 m. High Alt Med Biol. 2011;12: 89-92. doi:https://doi.org/10.1089/ham.2009.1094.

21. Enoch AJ, English M, Shepperd S. Does pulse oximeter use impact health outcomes? A systematic review. Arch Dis Child. 2016;101:694-700. doi: https://doi.org/10.1136/archdischild-2015-309638.

22. Ginsburg AS, Izadnegahdar R, Klugman KP. World Pneumonia Day 2016: pulse oximetry and oxygen. Lancet Glob Heal. 2016;4:e893-4. doi:https://doi. org/10.1016/S2214-109X(16)30296-0.

23. von der Weid L, Gehri M, Camara B, Thiongane A, Pascual A, Pauchard J-Y Clinical signs of hypoxaemia in children aged 2 months to 5 years with acute respiratory distress in Switzerland and Senegal. Paediatr Int Child Health. 2018;38:113-20. doi:https://doi.org/10.1080/20469047.2017.1390828.

24. Duke T, Subhi R, Peel D, Frey B. Pulse oximetry: technology to reduce child mortality in developing countries. Ann Trop Paediatr. 2009;29:165-75. doi: https://doi.org/10.1179/027249309X12467994190011.

25. Floyd J, Wu L, Hay Burgess D, Izadnegahdar R, Mukanga D, Ghani AC. Evaluating the impact of pulse oximetry on childhood pneumonia mortality in resource-poor settings. Nature. 2015;528:53-9.

26. Crocker ME, Hossen S, Goodman D, Simkovich SM, Kirby M, Thompson LM, et al. Effects of high altitude on respiratory rate and oxygen saturation reference values in healthy infants and children younger than 2 years in four countries: a cross-sectional study. Lancet Glob Heal. 2020;8:e362-73. doi:https://doi.org/10.1016/\$2214-109X(19)30543-1.

\section{Publisher's Note}

Springer Nature remains neutral with regard to jurisdictional claims in published maps and institutional affiliations.
Ready to submit your research? Choose BMC and benefit from:

- fast, convenient online submission

- thorough peer review by experienced researchers in your field

- rapid publication on acceptance

- support for research data, including large and complex data types

- gold Open Access which fosters wider collaboration and increased citations

- maximum visibility for your research: over $100 \mathrm{M}$ website views per year

At BMC, research is always in progress.

Learn more biomedcentral.com/submissions 